\title{
The Relationship Between Optimism and Subjective Well-Being in Covid-19 Pandemic Context
}

\author{
Garvin Garvin $^{1 *}$ Rahuel Adhi Putri ${ }^{1}$ \\ ${ }^{1}$ Faculty of Social Sciences \& Humanities, Bunda Mulia University, Jakarta 14440, Indonesia \\ *Corresponding author. Email: garvin.goei@gmail.com
}

\begin{abstract}
Work from home and social distancing that were implemented during the Covid-19 pandemic caused various psychological complaints such as boredom, anxiety, and even frustration. Especially for employees who work, the covid-19 pandemic provides uncertainty about the sustainability of their jobs. It is reported that many layoffs have occurred as a result of this pandemic. These things have the potential to reduce subjective well-being. This study intends to examine the relationship between optimism and subjective well-being. 368 participants $(62.5 \%$ women) were included in this study, where participants were asked to complete the Explanatory Style Test and the Subjective Well-Being Assessment Scale. The results of the correlation test found that there was a significant and positive relationship between optimism and subjective and well-being. This study suggests that individuals can embrace optimistic attitude during the Covid-19 pandemic in order to maintain their subjective well-being.
\end{abstract}

\section{Keywords: Covid-19, Optimism, Subjective Well-Being}

\section{INTRODUCTION}

The Covid-19 outbreak began at the end of 2019 and has become a global problem throughout 2020. According to WHO [1], Covid-19 is an infectious disease caused by the newly discovered corona virus. People affected by Covid19 mostly experience mild to severe respiratory problems, even pneumonia. Even though Covid-19 patients can recover without any special treatment, Covid-19 can also cause death, especially for those with medical problems. In order to prevent the spreading of Covid-19, various countries have implemented social distancing regulation, where everyone is asked to maintain physical distance from each other and not making crowd. Although social distancing able to prevent the spreading of Covid-19, social distancing is reported to have negative psychological effects, such as anxiety, boredom, even frustration [2].

The stress that comes from the Covid-19 pandemic can be categorized into three categories: (1) academic stress, (2) job stress, and (3) stress in the family [3]. This happens because various activities are conducted online, resulting to boredom and uncertainty about when this pandemic will end. Regarding to job stress, employees also reported that they encountered various difficulties when working from home. Some of the main struggles are, (1) collaboration and communication, (2) loneliness, and (3) unable to unplug [4]. This condition may decrease subjective wellbeing.

Subjective well-being is an individual's evaluation of his life [5]. Subjective well-being can be defined as the level at which an individual assesses the overall quality of his life as a whole in a beneficial way [6] or individual's evaluation of their life includes cognitive evaluation about life satisfaction and affective evaluation about mood and emotions [7].

People need to maintain their positive thoughts during this pandemic. In fact, the impact of the WFH / lockdown has been felt by workers. Some people must be unemployed or closed their business during the social distancing period. Approximately, employers had laid 162,416 employees off [8], causing unemployment in Jakarta and other cities in Indonesia. It may affect well-being. However, people can maintain their well-being by creating optimistic attitude toward these problems [9].

Chang and McBride [10] stated that optimism is related to the positive results desired by a person, such as good moral conditions, satisfying achievement, and the ability to solve problems that had been arisen. Optimism is a style of explanation and a positive mindset for the future when individuals think about the causes of an experience [11]. Carver, Scheier and Segerstrom [12] stated that optimism reflects the extent to which individuals have positive expectations for their future. Optimism can be defined as a person's belief that good results will happen to him. According to Scheier, Carver \& Bridges [12] Optimistic individuals tend to focus on how the problems can be handled effectively rather than avoiding or denying problems. Contrary to optimism, pessimism is defined as the belief that bad results will always occur. Meanwhile, according to Scheier, Weintraub \& Carver [13] pessimistic individuals tend to see existing problems as disasters and beyond their control. Rather than focusing on problem 
solving, pessimistic individuals tend to focus on the emotions they feel.

Khoirunnisa \& Ratnaningsih [14] founded that there is a positive relationship between optimism and psychological well-being in medical students of the Faculty of Medicine of Diponegoro University. The higher the optimism, the higher the student's psychological well-being, vice versa. The research conducted by Sahai \& Mahapatra [15] concluded that optimism is positively correlated with subjective well-being in employees. These various considerations led researchers to conduct research on optimism and subjective well-being in Covid-19 pandemic period.

\subsection{Optimism}

Seligman [11] defines optimism as an explanatory style and positive mindset to the future when individuals think about the causes of an experience. Optimism is a condition for someone who can show confidence in something that will happen in the future [16]. According to Schulman in Gillham, Shatte, Reivich and Seligman [17], someone who is optimistic will tend show high academic achievement in college and increased work productivity. Optimists also have more confidence about the future which leads them to continue their efforts towards the expected goals even though there are some struggles in achieving the goals [18]. Optimism consists of three dimensions: (1) temporary versus permanence, (2) specific versus pervasive, and (3) impersonal versus personal [11].

Temporary versus permanence. This dimension relates to how the individual views the duration of the events that occur in his life. An optimistic individual will see bad events as temporary, while a pessimist views bad events as permanent.

Specific versus pervasive. This dimension is related to the scope of how a bad event occurs, divided into specific and pervasive. Optimists view bad events specifically, while pessimists view bad events as universal.

Impersonal versus personal. This dimension relates to the sources of problems. Optimists see that the problem comes from external factors and thus they can deal with it, while pessimists see the problem as coming from internal factors so the problem could not be avoided.

\subsection{Subjective Well-Being}

Subjective well-being is an individual's evaluation of his life [6]. According to Eid \& Larsen [19] subjective wellbeing is a comprehensive domain that includes a wide collection of constructs about individual subjective evaluations of their quality of life. An individual has high subjective well-being when they feel satisfied with their life condition, and feel more positive affect than negative affect. Subjective well-being consists of six aspects [20]: positive experience, negative functioning, spirituality, social functioning, human instability, and economic stability.
- Positive experience. Relates to pleasant emotional experiences experienced by individuals.

- Negative functioning. Associated with unpleasant emotional experiences, physical pain, or difficulties in carrying out daily activities.

- Spirituality. Spirituality is a transcendent dimension related to the final goal in life, giving meaning to existence, and one's contribution to life.

- Social functioning. Regarding the role and interactions of a person in society, whether he is respected and valued by the members of the community.

- Human instability. Associated with feelings of insecurity, fear of loss, feelings of being threatened and lack of resources.

- Economic stability. With regard to economic security, including the level and stability of income.

\section{RESEARCH METHODS}

\subsection{Design}

The study is a quantitative correlational research involving 368 participants $(62.5 \%$ female) who were working from home due to the Covid-19 pandemic. Researchers did not differentiate the participants based on ethnicity and religion. The sampling technique used was non-random sampling and was carried out in Jakarta. The research questionnaire was distributed online, which contained two measuring scales, namely: (1) Explanatory Style Test, and (2) Subjective Well-Being Assessment Scale. The research questionnaire was created using Google Form and distributed through various groups on social media.

\subsection{Participants}

Three hundred sixty-eight Indonesian participants (62.5\% female) who was working from home during Covid-19 pandemic were asked to fill the research questionnaire. The mean age of the participants was 27.4 ( $\mathrm{SD}=5.3$ ) years. In addition, all of the participants were still working during the Covid-19 pandemic and all were domiciled in Jakarta.

\subsection{Measurements}

All of the measures were administered in Bahasa Indonesia. Optimism was assessed with Explanatory Style Test [6]. It contains 48 items about how they will respond in a certain situation. Each item consists of two answer choices. The 20-item Subjective Well-Being Assessment Scale [20] was used to assess subjective well-being. It measures six factors of subjective well-being: positive experience, negative functioning, spirituality, social functioning, human instability, economic stability. The scale uses a 5-point Likert-type scale form from 1 (very disagree), 2 (disagree), 3 (uncertain), 4 (agree), 5 (very agree). 


\section{RESULT \& DISCUSSION}

\subsection{Result}

Correlational analysis was conducted to assess the relationship between optimism and subjective well-being of the participants. The correlation analysis was using Pearson's correlation analysis technique because the data is normally distributed. The result of Pearson's correlation test indicated that optimism is significantly correlated with subjective well-being $(\mathrm{p}=0.004<0.05, \mathrm{r}=0.15)$. It means that when optimism increases, subjective well-being will also increase, vice versa. However, the relationship between the two variables is low $(r=0.150)$.

\subsection{Discussion}

Based on the result of the study, there is a positive and significant relationship between optimism and subjective well-being on adults who are working from home during the Covid-19 pandemic. This finding is consistent with previous findings. Nurzulia \& Nursanti [21] found that optimism is related to subjective well-being on outsourcing employees. The relationship between optimism and subjective well-being is often discussed in research. Study by Sahai \& Mahapatra [15] found that optimism is positively correlated with subjective wellbeing in employees. Sabiq \& Muftahuddin [22] also found that optimism is correlated with subjective well-being on nurse. Optimist workers can control the stress they perceived at work. Thus, they are more able to cope the stress and have better subjective well-being than pesimist workers. Besides, the optimists perceived more selfconfidence, work involvement, and organizational support so they will experience more positive emotions than the pessimists [23]. Not only on workers, optimism is also known to be related to subjective well-being in adolescents [24] and college students as well [25]. The role of optimism in increasing subjective well-being does not differ based on gender [26]. Thus, the finding implies that optimism is a variable that can be associated with subjective well-being in various contexts and ages.

\section{CONCLUSION}

In this study, we found that optimism is positively correlated with subjective well-being in working from home employees in Jakarta. This founding suggest that even work from home and social distancing is somewhat boring and even frustrating, but optimism can help to maintain the subjective well-being during Covid-19 pandemic. To embrace optimism, people should perceive that these negative experiences during pandemic are temporary, specific, and impersonal. Although when the end of the pandemic is still unclear, there is still hope that this pandemic can end. Thus, stay optimistic with realistic expectations to maintain the subjective well-being is an attitude we can have while facing the pandemic.

\section{REFERENCES}

[1] World Health Organization. Coronavirus. 2020. Retrieved from https://www.who.int/health-topics/ coronavirus.

[2] American Psychological Association. Keeping your distance to stay safe. 2020. Retrieved from https://www.apa.org/practice/programs/dmhi/ researchinformation/social-distancing.

[3] M. Muslim. Manajemen stres pada masa pandemi Covid-19, Esensi: Jurnal Manajemen Bisnis. 23(2) (2020) 192-201.

[4] Buffer \& AngelList. The state of remote work survey. (2020) Retrieved from https://lp.buffer.com/ state-of-remote-work-2020.

[5] E. Diener. New findings and future directions for subjective well-being research. American Psychologist. 67(8) (2020) 590-597. DOI: http://dx.doi.org/10.1037/ a0029541.

[6] E. Diener. Assessing well-being: the collected works of Ed Diener. USA: Springer Science \& Business Media, 2009. DOI: 10.1007/978-90-481-2354-4.

[7] H. Y. Wicaksana, A.R. Shaleh, Pengaruh optimisme dan social support terhadap subjective well-being pada anggota bintara pelaksana Polri, TAZKIYA Journal of Psychology, 22(2) (2017) 241-254.

[8] P. Kurniati. PHK karyawan di sejumlah daerah imbas wabah corona, mana saja? 2020. Retrieved from https://regional.kompas.com/read/2020/04/09/06100071 /phk-karyawan-di-sejumlah-daerah-imbas-wabahcorona-mana-saja.

[9] J. Ariati. Subjective well-being (kesejahteraan subjektif) dan kepuasan kerja pada staf pengajar (dosen) di lingkungan Fakultas Psikologi Universitas Diponegoro, Jurnal Psikologi Undip, 8(2) (2010) 117123. DOI: https://doi.org/10.14710/jpu.8.2.

[10] L. Chang, McBride. The factor structure of the LOT. Educational and Psychological Measurement, 56(2) (1996) 325-329.

[11] M. E. Seligman. Learned optimism: how to change your mind and your life. New York: Pocket Books, 2006.

[12] S. S. Carver, M. F. Scheier. Optimism, in: C. R. Snyder \& S. J. Lopez (Eds.), Handbook of positive 
psychology, New York, Oxford University Press, 2002, pp.63-73.

[13] M. F. Scheier, J. K. Weintraub, C. S. Carver. Coping with stress: Divergent strategies of optimism and pessimists, Journal of Personality and Social Psychology, 51(6) (1986) 1257 - 1264.

[14] A. Khoirunnisa, I. Z. Ratnaningsih. Optimisme dan kesejahteraan psikologis pada mahasiswa Pendidikan Dokter Fakultas Kedokteran Universitas Diponegoro, Jurnal Empati. 5(1) (2016) 1-4.

[15] A. Sahai, M. Mahapatra. Optimism and subjective well-being of employees. 4th International Conference on Advances in Management \& Digital Sciences, 2019.

[16] A. Donatta. Design your hope: Prinsip dan langkah menumbuhkan harapan diri sendiri. Jakarta: Gramedia Pustaka Utama, 2018.

[17] J. E. Gillham, A. J. Shatté, K. J. Reivich, \& M. E. P. Seligman. Optimism, pessimism, and explanatory style, in E. C. Chang (Ed.), Optimism \& Pessimism, Washington DC, American Psychological Association, 2001.

[18] M.M. Hanssen, L.M.G. Vancleef, J.W.S., Vlaeyen, A.F. Hayes, E.G.W. Schouten, \& M.L. Peters. Optimism, motivational coping and well-being: evidence supporting the importance of flexible goal adjustmen, Journal of Happiness Study, 16 (2015) 1525-1537. DOI: 10.1007/s10902-014-9572-x.

[19] Eid, M. \& Larsen. The science of subjective wellbeing. New York: The Guilford Press, 2008.

[20] G. Veronese, A. Pepe, G. Sala, I. Yamien, \& M. Vigliaroni. Positive experience, psychological functioning, and hope for the future as factors associated with mental health among young SubSaharan internally displaced people, International Journal of Mental Health, 48(3) (2019) 1-23. DOI: 10.1080/00207411.2019.1635849.

[21] S. Nuzulia, H.D. Nursanti. Hubungan optimisme dengan subjective well-being pada karyawan outsourcing PT Bank Rakyat Indonesia cabang Cilacap, Intuisi: Jurnal Psikologi Ilmiah, 4(2) (2012) 1-5. DOI: 10.15294/intuisi.v4i2.13333.

[22] Z. Sabiq, Miftahuddin. Pengaruh optimisme, dukungan sosial, dan faktor demografis terhadap kesejahteraan subjektif pada perawat, Jurnal Pengukuran Psikologi Pendidikan Indonesia, 6(2) (2017) 183-196. DOI: 10.15408/jp3i.v6i2.9174.
[23] A. Singhal, P. Nema, B. Priya. Assessing the impact of self-esteem \& optimism on subjective wellbeing: A moderation model, International Journal of Advanced Science and Technology, 29(1) (2020) 3363337.

[24] B. Duy, M.A. Yuldiz. The mediating role of selfesteem in the relationship between optimism and subjective well-being, Current Psychology, 38 (2019) 1456-1463. DOI: https://doi.org/10.1007/s12144-0179698-1

[25] K.L. Rand, M.L. Shanahan, I.C. Fisher, S.K. Fortney. Hope and optimism as predictors of academic performance and subjective well-being in college students, Learning and Individual Differences, 81 (2020) $1-9$

[26] M.Y. Ho, F.M. Cheung, S.F. Cheung. The role of meaning in life and optimism in promoting well-being, Personality and Individual Differences, 48(5) (2010) 658-663. DOI: https://doi.org/10.1016/j.paid.2010.01. 008 